\title{
The Impact of Soil Erosion on Agricultural Potential and Performance of Sheshegu Community Farmers in the Eastern Cape of South Africa
}

\author{
Ikponmwosa D. Ighodaro $^{1}$, Francois S. Lategan ${ }^{2} \&$ Shehu F. G. Yusuf ${ }^{1}$ \\ ${ }^{1}$ Researchers of Agricultural Extension, Department of Agricultural Economics and Extension, Faculty of Science \\ and Agriculture, University of Fort Hare, Alice main campus, South Africa \\ ${ }^{2}$ Professor of Agricultural Extension, Department of Agricultural Economics and Extension, Faculty of Science \\ and Agriculture, University of Fort Hare, Alice main campus, South Africa \\ Correspondence: Ikponmwosa D. Ighodaro, Department of Agricultural Economics and Extension, Faculty of \\ Science and Agriculture, University of Fort Hare, Alice main campus, Private Bag X1314, 5700, South Africa. \\ E-mail:ikdavid2004@yahoo.com
}

Received: December 21, 2012; Accepted: February 18, 2013; Online Published: April 15, 2013

doi:10.5539/jas.v5n5p140

URL: http://dx.doi.org/10.5539/jas.v5n5p140

\begin{abstract}
Soil erosion is one of the unresolved problems of rural agriculture. This study investigates the impact of soil erosion on the agricultural potential and performance of Sheshegu community farmers in the Eastern Cape of South Africa. Structured interview scheduled was used to collect data from 50 respondents using simple random sampling. Findings revealed that most (62\%) respondents are male, who are above 46 years old $(68 \%)$. Most of whom $(72 \%)$ had education above grade 7 . Further, the majority of them $(50.8 \%)$ depend on social grants as sources of income. Most respondents confirmed that erosion occurred naturally through heavy rainfall and persistent drought while human causes that facilitated erosion include farming activities, deforestation and indiscriminate bush burning that expose soil to impact of rain drop. Respondents affirmed that erosion contributed to poor health of livestocks due to lack of pasture grass to feed on, loss of grazing land and poor bush regrowth. It is recommended that awareness on the negative effect of human causes of erosion should be created while simple technologies on soil erosion control should be pushed to the farmers. Finally, edict on bush burning should be enforced to check indiscriminate bush burning.
\end{abstract}

Keywords: soil erosion, agricultural potential, farmers' perception

\section{Introduction}

Soil erosion is a critical global land degradation phenomenon affecting human beings since humanity's basic sources of livelihood is from the land. However, changes in land use worldwide have been recognized as capable of accelerating soil erosion (Chappell et al., 2010). Degraded soil is unproductive, which is also determined by the degree of severity to land damage. Soil worldwide is being degraded at a phenomenal rate. According to the Centre for Science and Environment (CSE) (1985), soil erosion affects between 25-30 per cent of the total land under cultivation in India. In South Africa over 70\% of the nation's land surface has been impacted by varying levels and types of soil erosion (Pretorius, 1998; Garland et al., 2000; Le Roux, Newby, \& Sumner, 2007). Similarly, FAO (1984) indicates that without any conservation measures, the total area of rain-fed cropland in developing countries in Africa, Asia and Latin America would in long-term get smaller by 544 million hectares because of soil erosion and degradation. On a global scale, the Food and Agriculture Organization (FAO) estimates that the loss of productive land through soil erosion globally is about 5-7 million ha/year (Kumar and Ramachandra, 2003). Many scholars projected that unless there is an adoption of better land management practices, about 140 million hectares of high quality soil, in Africa and Asia, would have been degraded as a result of soil erosion by 2010 (FAO, cited in Kumar \& Ramachandra, 2003). This unveils the danger of soil erosion activities and the need for appropriate soil management practices, as well as a concerted effort in the fight against its effects.

According to Ojo and Johnson (2010) soil erosion is a dynamic geomorphic event operating on the landscape. Further, Jones (2007) defined soil erosion as "the wearing away of the land surface by physical forces such as rainfall, runoff water, wind, ice, temperature change, gravity or other natural or anthropogenic agents that abrade, detach and remove soil or geological material from one point on the earth's surface to be deposited elsewhere". However, Marsh and Grossa (2005) simply define soil erosion as the dislodgement of particles from the soil. 
According to these definitions, there exist the gradual detachments of top-soil particles, which are transported by agents of denudation, such as water and wind, and subsequently deposited elsewhere. Toy, Foster and Renard (2002) explained that erosion can be "geologic" or "accelerated". Geologic erosion is naturally on-going within the earth crust. The erosion rate is so slow that it is of less importance to human beings. But accelerated erosion is caused by human-beings.The erosion rate is so high that it has resulted in different focuses by soil scientists and scholars in related disciplines. Therefore, this study is focussing on accelerated soil erosion activities in Sheshegu community.

Future world population requires increased food production (Pimentel, 2006). For example, the world population is said to have grown to 7.06 billion in middle of 2012, after having crossed the 7 billion mark in 2011 (Haub, 2012). Further, the 79.3 million people added to the overall global population each year has been consistent for nearly a decade (Engelman, 2010). This means that there is need to increase agricultural produce to feed this additional millions of people each year with food. Without the soil, this is not possible. Hence damage, through soil erosion or in any other forms, to the soil is an indirect damage to agricultural production and ultimately food security. According to Wall, Baldwin and Shelton (1987), the implication of soil erosion extends beyond the removal of valuable topsoil. In fact, crop emergence, growth and yield are directly affected through the loss of natural nutrients. Bathrellos, Skilodimou and Chousianitis (2010), commenting on how soil erosion could impact on farming, states that the main on-site impact of soil erosion is the reduction of soil quality which results from the loss of the nutrient-rich upper layers of the soil and the reduced water-holding capacity of many eroded soils.

Soil erosion has enormous negative impact on agriculture. Research shows that in most developing countries, especially Sub-Saharan Africa $60-70 \%$ of the population in the rural areas depend on agriculture to earn a livelihood (Loulseged \& McCartney, 2000). The percentage of the population depending on agriculture is more in Ethiopia as about $85 \%$ of the population live in rural areas and they depend on agriculture to earn a livelihood (Düvel, Chiche \& Steyn, 2003). It is therefore imperative that farmers' perception about the negative impact of soil erosion as it affects agricultural production be taken into consideration. This is because perception has a great influence in the type of behaviour displayed by farmers (Berelson \& Steiner, 1964). According to Duvel (1991) among the reasons for most agricultural problems is the farmers' in-adoption or inappropriate adoption of agricultural technologies which are rooted in the perceptions displayed by the farmers. Perception, according to Lewin (1951), one of the foremost authors in the behavioural studies, as reported by Shaw and Constanzo (1970), is a behavioural product of individual life space or what he also calls the psychological environment. In this life space, perception plays a dominant role.

Therefore, this paper seeks, among other things, to unfold the impact of soil erosion on the agricultural potential and performance of farmers in Sheshegu community, in the Eastern Cape. The study also focuses on how farmers in the study area experience the impact of soil erosion on their agricultural productivity. The underlying questions are: do farmers view soil erosion in their area as a problem? If they do, how much of a problem do they see it to be? What are some of the underlying reasons for soil erosion problem in the area? And how does it affect their agricultural productivity?

\section{Aim and Objectives of the Study}

The aim of this paper is to have clear understanding of the challenges of soil erosion from the perception of the farmers and the necessity to implement conservation measures in the study area. The specific objectives are:

1) To identify farming practices that accelerates soil erosion in the study area.

2) To discuss the perception of the farmers in relations to the impact of soil erosion on the agricultural potentials and performance of the Sheshegu community.

\section{Decription of the Study Area}

Sheshegu is a small rural community in Nkonkobe Municipality, Eastern Cape Province of South Africa. It is located on the South West of Alice along R345 road to Peddie, and its position is on longitude $26^{\circ} 44^{\prime} 47^{\prime \prime} .9$ and $26^{\circ}$ $50^{\prime} 55^{\prime \prime} .2 \mathrm{E}$ of Greenwich, and latitude $32^{\circ} 53^{\prime} 06^{\prime \prime} .1 \mathrm{~S}$ and $32^{\circ} 56^{\prime} 36^{\prime \prime} .0 \mathrm{~S}$ of the equator (Google earth, 2009). It is composed of six smaller villages, namely: Mpozisa, Skolwoni, Baluia, Lower Sheshegu, Sheshegu Fingo and Komkhalu respectively. Its lithology is of mudstone and sandstone, and it has a savannah type of vegetation. The inhabitants are mainly Xhosa speaking people relying on animal farming. Although the 2002 Census data indicates that the main land use type of Sheshegu is sheep farming (Statistics South Africa, 2002), there are other animals being reared in the area. Crop farming is hardly practised in the area due to the nature of the soil. 


\section{Methodology}

The survey method of research was adopted for this study. Questionnaires were used during the data collection process. Data collection was through a one-on-one collection process, and the sampling technique adopted was the simple random sampling, in which the services of the researcher and three other survey assistants were employed. A Likert scale of 1-3 was adopted for the study, where 1, 2 and 3 represent insignificant, moderately significant and very significant respectively. A total of 50 farmers were interviewed and their responses form the basis of this study. Data analysis was executed using SPSS software package version 19 for both descriptive and inferential statistics.

\subsection{Problem Conceptualization}

The basis of problem conceptualization is based on the notion that "a problem well put, is a problem half solved" (Düvel, 1991). Problem conceptualization is a hypothetical construct providing a scientific basis for purposeful and systematic probing into the causes of a problem (Düvel, 1991). It is very relevant in agricultural studies, because it assists in the breaking down of agricultural problems into easily manageable units. The Düvel (1991) model was adopted for this study because of its particular relevance. It links human behaviour and its outcomes in an interrelated causal relationship with environmental factors through a decision making process (Ighodaro \& Lategan, 2012).

\subsection{Specific Variables Analysed (Dependent and Independent)}

Table 1. Specific variables analysed in the study

\begin{tabular}{|c|c|}
\hline Variables & Descriptions \\
\hline Education level (independent) & Highest level of education as at the time of interview \\
\hline Gender (independent) & Is the farmer a male or female? \\
\hline Age of farmer (independent) & How old is the farmer as at time of interview? \\
\hline $\begin{array}{l}\text { Contribution of sources of income } \\
\text { (independent) }\end{array}$ & $\begin{array}{l}\text { Percentage contribution of various sources of income to } \\
\text { total income of the farmer }\end{array}$ \\
\hline Perceived severity of soil erosion (dependent) & $\begin{array}{l}\text { Likert scale rating of farmers' perception on the severity } \\
\text { of soil erosion }\end{array}$ \\
\hline $\begin{array}{l}\text { Perceived increase rate of soil erosion } \\
\text { (dependent) }\end{array}$ & $\begin{array}{l}\text { Likert scale rating of farmers' perception on increase of } \\
\text { soil erosion in the past ten years }\end{array}$ \\
\hline \multirow[t]{2}{*}{ Perceived causes of soil erosion (independent) } & Three main natural causes of soil erosion \\
\hline & Three main human causes of soil erosion \\
\hline \multirow{4}{*}{$\begin{array}{l}\text { Perceived impact of soil erosion on agricultural } \\
\text { productivity and performance (independent) }\end{array}$} & Impact of soil erosion on farmers' profitability \\
\hline & Impact of soil erosion on quality of product \\
\hline & Impact of soil erosion on yield of crops \\
\hline & Impact of soil erosion on farmers' sustainability \\
\hline
\end{tabular}

\section{Results and Discussion}

\subsection{Demographic Profile of Farmers}

Table 2 presents the demographic profile of the farmers in the study area. The results indicate that the majority $(62 \%)$ are males while females (38\%) are of the minority. The majority of the farmers are in the age group bracket of 46-55 years old (22\%) and 66-75 years old (22\%). The average age was 52.91 years old indicating the problem of ageing phenomenon (Ayinde, 2011) confronting the farming occupation nowadays. The youths are no longer interested in farming activities thereby migrating to the cities for white collar jobs. Similarly, majority (36\%) of the farmers had educational attainment of between grades 7-10 while only 6\% exceeded grade 12 showing that education level of farmers in the area is low. As reported, inadequate education and poverty are two key characteristics which impact on farmers' poor farming decisions and/ or perceptions which result to soil erosion (Pender \& Hazell, 2000). Findings further indicated that most (50.80\%) of the farmers depends on social grants as sources of income (Table 2). 
From all indications in Table 2, apart from other income source which consists largely of the government welfare grants, farming $(29.36 \%)$ seems to be the main source of income for farmers in the study area, which indicates the main human activity responsible for soil erosion in the area. Similarly Table 2 reveals that income from animal farming is largest, which seems to concur with the National Census data of 2002 that the main land use type of study area is sheep farming (Statistics South Africa, 2002) and thus the main farming type responsible for erosion in the area.

Table 2. Socioeconomic profile of Sheshegu farmers

\begin{tabular}{|c|c|c|c|}
\hline Items & Frequency & \multicolumn{2}{|c|}{ Percentage } \\
\hline Male & 31 & \multicolumn{2}{|l|}{$62 \%$} \\
\hline Female & 19 & \multicolumn{2}{|l|}{$38 \%$} \\
\hline Total & 50 & \multicolumn{2}{|l|}{$100 \%$} \\
\hline \multicolumn{4}{|l|}{ Age according to gender } \\
\hline Age & Frequency & $\begin{array}{l}\text { Percen } \\
\text { tage }\end{array}$ & Mean \\
\hline$<35$ & 6 & 12 & \\
\hline $36-45$ & 10 & 20 & \\
\hline $46-55$ & 11 & 22 & 52.91 years \\
\hline $56-65$ & 8 & 16 & \\
\hline $66-75$ & 11 & 22 & \\
\hline $76-85$ & 4 & 8 & \\
\hline Total & 50 & 100 & \\
\hline Educational status & Frequency & $\%$ & \\
\hline No formal education & 6 & 12 & \\
\hline Grade 1-3 & 5 & 10 & \\
\hline Grade 4-6 & 10 & 20 & \\
\hline Grade $7-10$ & 18 & 36 & \\
\hline Grade $11-12$ & 8 & 16 & \\
\hline Diploma & 3 & 6 & \\
\hline Total & 50 & 100 & \\
\hline Sources of income & & & Contributions (\%) \\
\hline Government & & & 13.94 \\
\hline Private & & & 3.9 \\
\hline Farming & & & 29.36 \\
\hline Self employed & & & 2 \\
\hline Other sources (e.g grants) & & & 50.8 \\
\hline Total & & & 100 \\
\hline Types of farming practice & by the farmers & & Contributions (\%) \\
\hline Crop farming & & & 5.85 \\
\hline Enclosed animal farming & & & 30.05 \\
\hline Free-range animal farming & & & 64.10 \\
\hline Total & & & 100 \\
\hline
\end{tabular}

Source: Survey research, 2010. 


\subsection{Basic Causes of Soil Erosion in the Study Area}

Table 3 indicates the perceived main natural causes of soil erosion in Sheshegu community by the respondents. Findings reveal a wide variety of possible natural causes which are perceived to be responsible for the erosion in the research area. However, the basic ones in order of preference, are rainfall, drought, winds, and climate change. Speaking on the causes of soil erosion, Pimentel (2006) suggested that soil erosion results from actions that expose the soil to rainfall or wind. Similarly, citing Cook and Reeves (1976), Whitlow (1989) maintained that gully (which is one of the devastating forms of soil erosion) development is seen as the result of three sets of factors interacting together. These are (1) land use changes; (2) secular (long-term) climate changes; and (3) random frequency-magnitude variations such as inherent disadjustments in the long profiles of channels.

Table 3.Frequency distribution (\%) of perceived natural causes of soil erosion in Sheshegu

\begin{tabular}{llll}
\hline Causes of erosion & Priority $\mathbf{1}$ & Priority $\mathbf{2}$ & Priority $\mathbf{3}$ \\
\hline Climate change/variation & 4 & 10 & 6 \\
Drought & 38 & 14 & 10 \\
Rainfall & 36 & 39 & 25 \\
Winds & 16 & 18 & 20 \\
Lack of adequate drainage & 3 & 3 & 6 \\
Nature of the soil & 1 & 5 & 10 \\
Slope/gradient of land & 1 & 8 & 12 \\
Bare land & 1 & 3 & 11 \\
Total & 100 & 100 & 100 \\
\hline
\end{tabular}

Source: Survey research, 2010.

Table 4 indicates that the types of agricultural activities on the field are the major factors responsible for the acceleration of erosion in the study area. Other human causes include building or construction, deforestation and indiscrimate veld/ bush burning. According to Zalidis et al. (2002), the detrimental effects of agricultural practices on soil quality include erosion, desertification, salinization, compaction and pollution. Ofomata (1975) confirmed that the intensive concentrations of domestic animals and the indiscriminate bush burning have increased the rate of soil erosion in Nigeria. Snyman (1999) maintained that although soil erosion is considered as a natural process, it is often accelerated by human activities such as clearing of vegetation (deforestation) or by overgrazing.

Table 4. Frequency distribution (\%) of the perceived human causes of soil erosion in Sheshegu

\begin{tabular}{llll}
\hline Human causes & Priority $\mathbf{1}$ & Priority 2 & Priority 3 \\
\hline Agricultural activities & 28 & 18 & 16 \\
Animal/human footpath & 8 & 12 & 8 \\
Building purposes & 20 & 24 & 16 \\
Deforestation & 20 & 20 & 8 \\
Tradomedical uses & 2 & 4 & 2 \\
Veld fires/burning & 14 & 12 & 10 \\
Irrigation water & 0 & 2 & 0 \\
Improper soil management. & 0 & 0 & 4 \\
No response & 8 & 8 & 36 \\
Total & 100 & 100 & 100 \\
\hline
\end{tabular}

Source: Survey research 2010. 


\subsection{Perceived Impact of Soil Erosion on the Agricultural Potential and Performance in the Study Area}

Table 5. The impact of soil erosion on Sheshegu farming operations

\begin{tabular}{lcccccc}
\hline Impact of erosion on Sheshegu farming & F1 & P1 & F2 & P2 & F3 & P3 \\
\hline Affects animal health (negatively) & 9 & 18 & 18 & 36 & 6 & 12 \\
Affects human health & - & - & 3 & 6 & - & - \\
Affect farmers' income & - & - & - & - & 3 & 6 \\
Drought & 3 & 6 & 3 & 6 & 3 & 6 \\
Development of gullies & - & - & 2 & 4 & 2 & 4 \\
Destruction of plants & - & - & - & - & 1 & 2 \\
Lack of shade for animals & - & - & 1 & 2 & - & - \\
Poor growth/production of crops & 8 & 16 & 7 & 14 & 2 & 4 \\
Shortage of grazing/farmland & 23 & 46 & 2 & 4 & 5 & 10 \\
Shortage of land for other uses & - & - & 1 & 2 & - & - \\
Siltation of dams & 1 & 2 & 1 & 2 & 3 & 6 \\
Unproductive soils & 2 & 4 & 4 & 8 & - & - \\
No response & 4 & 8 & 8 & 16 & 25 & 50 \\
Total & 50 & 100 & 50 & 100 & 50 & 100 \\
\hline
\end{tabular}

Source: Survey research 2010 (F= Frequency and $\mathrm{P}=$ Percent).

According to Table 5 above, the impact of soil erosion on the agricultural potential of study area was expressed in terms of three basic indicators: negative effect on animal health, shortage of grazingland and farmland and poor production of crops. The data collected proves that these three variables score the highest responses.

In the same table, the cumulative percentage responses of individual farmer in the study area are expressed as follows: perceived impact of soil erosion on Sheshegu farming operations indicates a $66 \%$ for negative effect on animal health, $60 \%$ for shortage of grazingland or farmland and 34\% for poor crop growth. The implication of this is that agricultural production and overall rural development is under great danger. This is because, animals, which is the main farming type in Sheshegu is affected negatively, agricultural lands are progressively being reduced due to erosion activities, and growth of crops is being affected negatively as well.

From the study (Table 6), soil erosion was also perceived to impact significantly on different farming efficiency or performance aspects (profitability, product quality, yield and sustainability) in the study area. Farmers indicated that soil erosion impacted the most significantly on their profitability, product quality, yield and sustainability through the detrimental impact it has on grazingland, production of crops and on animal health, as depicted in the Table 6 below.

Table 6. Perceived impact of erosion on selected aspects of Sheshegu farming performance

\begin{tabular}{|c|c|c|c|c|c|c|c|c|c|c|c|c|}
\hline \multirow{2}{*}{ Soil erosion impact on farming } & \multicolumn{3}{|c|}{ Profitability } & \multicolumn{3}{|c|}{ Product quality } & \multicolumn{2}{|c|}{ Yield } & \multicolumn{4}{|c|}{ Sustainability } \\
\hline & $\mathrm{F} 1$ & $\mathrm{~F} 2$ & F3 & $\mathrm{F} 1$ & $\mathrm{~F} 2$ & F3 & $\mathrm{F} 1$ & $\mathrm{~F} 2$ & $\mathrm{~F} 3$ & F1 & $\mathrm{F} 2$ & F3 \\
\hline Affects animal health & 7 & 15 & 4 & 9 & 15 & 3 & 6 & 6 & 2 & 6 & 16 & 5 \\
\hline Affects human health & - & 1 & - & - & 1 & - & 1 & 1 & - & 1 & - & - \\
\hline Affects farmers' income & 1 & 1 & 1 & 1 & 1 & 1 & 1 & 1 & 1 & 1 & 1 & 1 \\
\hline Drought & 2 & 3 & 2 & 3 & 2 & 3 & 3 & 3 & 3 & 3 & 2 & 3 \\
\hline Gully development & 2 & 4 & - & 2 & 4 & - & 1 & 1 & - & - & 5 & 1 \\
\hline Destruction of plants & 1 & - & - & 1 & - & - & 1 & 1 & - & 1 & - & - \\
\hline Lack of shade for animals & - & - & 1 & - & - & 1 & - & - & 1 & - & - & 1 \\
\hline Poor growth of crops & 10 & 6 & - & 8 & 6 & 1 & 8 & 8 & 2 & 10 & 5 & - \\
\hline Shortage of grazing/farmland & 17 & 6 & 3 & 16 & 6 & 5 & 17 & 17 & 4 & 12 & 9 & 5 \\
\hline Shortage of land for other uses & - & 1 & 1 & 1 & 1 & - & 1 & 1 & - & 1 & 1 & - \\
\hline Siltation of dams & 1 & 2 & - & 1 & 2 & - & 1 & 1 & - & 1 & 2 & - \\
\hline Unproductive soils & 2 & 3 & 1 & 4 & 2 & 1 & 3 & 3 & - & 5 & 2 & - \\
\hline No response & 7 & 8 & 37 & 4 & 10 & 35 & 7 & 7 & 37 & 9 & 7 & 34 \\
\hline
\end{tabular}

Source: Survey research 2010 (F= Frequency). 


\section{Conclusion}

Amongst other things, soil erosion poses great danger to agricultural development anywhere in the world. The Eastern Cape, where this study was conducted, is regarded as one of the three most degraded provinces in South Africa. According to the findings in this study, the impact of soil erosion, in terms of its severity and rate on the agricultural potential and performance of farmers in Sheshegu community, is found to be negatively high. Similarly, the three most significant natural causes of erosion in the area are heavy rainfall, drought, and strong winds, while in terms of human causes, agricultural activities seem to enjoy the highest priority, followed by building purposes and deforestation activities. However, soil erosion impact is expressed in the form of negative effect on the health of animals, shortage of grazingland or farmland and poor growth of crops. It is therefore recommended that conserted efforts should be made towards educating the farmers on the danger inherent in inappropriate farming activities, indiscriminate bush burning and deforestaion. Edicts on bush burning should be enforced. Finally, simple methods of soil erosion control should be pushed to the farmers by extension services.

\section{References}

Adediji, A. (2000). The politics on erosion issues. In H. I. Jimoh \& I. P. Ifabiyi (Eds), Contemporary issues in environmental studies. Kwara State: Haylee Press and Publishing Company, Ltd.

Ayinde, A. F. O. (2011). Analysis of Ageing Farming Population and Agricultural Productivity among Cassava Farmers in the Rural Areas of Ogun and Ekiti States, Nigeria. Unpublished PhD Thesis, Department of Agricultural Extension and Rural Development, Federal University of Agriculture, Abeokuta, Nigeria

Bathrellos, G. D., Skilodimou, H. D., \& Chousianitis, K. G. (2010). Soil erosion assessment in southern Evia Island using USLE and GIS. Proceedings of the $12^{\text {th }}$ International Congress Patras. May, 2010.

Berelson, B., \& Steiner, G. A. (1964). Human behaviour: an inventory of scientific findings (pp. 87-121). New York: Harcourt, Brace \& World, Inc.

Chappell, A., Loughran, R., Rossel, R. V., \& Hancock, G. (2010). Time to establish a 137Cs-derived net soil redistribution baseline for Australia? 19th World Congress of Soil Science, Soil Solutions for a Changing World. 1-6 August 2010, [DVD] Brisbane, Australia.

Centre for Science and Environment (CSE). (1985). The state of India's environment 1984-85: a citizen's report. New Delhi: Centre for Science and Environment (Environment, 1985).

Düvel, G. H. (1991). Towards a model for the promotion of complex innovations through programmed extension. S. Afr. J. of Agric. Extension, 20, 70-86.

Düvel, G. H., Chiche, Y., \& Steyn, G. J. (2003). Maize production efficiency in the ArsiNegele farming zone of Ethiopia: a gender perspective. S. Afr. J. Agric. Ext./S. Afr. Tydskr. Landbouvoorl, 32, 60-72

Engelman, R. (2010). World population growth slows modestly, still on track for 7 billion in late 2011. Worldwatch Institute. Retrieved from http://vitalsigns.worldwatch.org/node/127

FAO. (1984). Land, food and people. Rome: A/42/427, Our Common Future: Report of the World Commission on Environment and Development.

Google earth. (2009). Google map. [O]. Retrieved from http://google-earth-pro.en.so(Earth,2009)ftonic.com

Haub, C. (2012). World population data sheet 2012. Population Reference Bureau. Retrieved from http://www.prb.org/Publications/Datasheets/2012/world-population-data-sheet/fact-sheet-world-population. aspx

Ighodaro, I. D. (2007). Analysis of gully erosion in Benin: a case study of Ekosodin Gully. Nigeria: Unpublished B.sc (Geo) dissertation, University of Benin.

Ighodaro, I. D. (2010). The role of agricultural extension in the control of soil erosion in Sheshegu community, Eastern Cape, South Africa. Unpublished B.A Agriculture (Honours), Agricultural Extension dissertation, University of Fort Hare, Alice.

Ighodaro, I. D., \& Lategan, F. S. (2012). The perceived role of inappropriate agricultural practices as basic cause of soil erosion in the Eastern Cape of South Africa: a case of study of Sheshegu Community. A paper presented at the Agricultural Economics Association of South Africa (AEASA), Bloemfontein, $1^{\text {st }}$ to $3^{\text {rd }}$ October, 2012.

Jones, B. (2007). Soil erosion. Paper presented at the Thematic strategy for soil protection, common criteria for risk area identification in the soil framework directive (pp. 1-27). $25^{\text {th }}$ April, 2007, BGR, Hannover. 
Kumar, R., \& Ramachandra, T. V. (2003). Water soil and sediment investigation to explore status of aquatic ecosystem. Bangalore: Centre for Ecological Sciences, India Institute of Science.

Le Roux, J. J., Newby, T. S., \& Sumner, P. D. (2007). Monitoring soil erosion in South Africa at a regional scale: review and recommendations. South African Journal of Science, 103.

Loulseged, M., \& McCartney, M. (2000). Agriculture and livelihoods in Sub-Saharan Africa. International Water Management Institute. Retrieved from http://ehproject.org/PDF/phe/loulseged-iwrm.pdf

Marsh, W. M., \& Grossa, J. (2005). Environmental geography: science, land use and earth systems (3rd ed.). United States of America: John Wiley \& Sons Inc.

Ofomata, G. E. K. (1975). Factors of soil erosion in Enugu area of Nigeria. Nigeria Geographic Journal (NGJ), $8(1), 45-59$.

Ojo, A. D., \& Johnson, O. (2010). Erosion problems in a Nigerian rural community. Journal of Sustainable Development in Africa, 12(1).

Pender, J., \& Hazell, P. (2000). Promoting sustainable development in less-favoured areas overview. Washington D.C.: International Food Policy Research Institute (IFPRI).

Pimentel, D. (2006). Soil erosion: a food and environmental threat. Environmental Development and Sustainability, 8, 119-137. http://dx.doi.org/10.1007/s10668-005-1262-8

Shaw, M. E., \& Constanzo, P. R. (1970). Theories of social psychology (pp. 122-125). New York: McGraw Hill.

Snyman, H. A. (1999). Soil erosion and conservation. In N. M. Tainton (Ed.), Veldt Management in South Africa (pp. 355-380). Pietermaritzburg: University of Natal Press.

Statistics South Africa. (2002). Statistics South Africa annual report 2002/2003, Pretoria.

Toy, T. J., Foster, G. R., \& Renard, K. G. (2002). Soil erosion: processes, prediction, measurement and control. New York: John Wiley and Sons Inc.

Wall, G., Baldwin, C., \& Shelton, S. (1987). Soil erosion-causes and effects. Retrieved from http://www.omafra.gov.on.ca/english/engineer/facts/87-040.htm

Whitlow, R. (1989). A review of Dambo gullying in South-Central Africa. Zambezia (1989), XVI (ii).

Zalidis, G., Stamatiadis, S., Takavakoglou, V., Eskridge, K., \& Misopolinos, N. (2002). Impacts of agricultural practices on soil and water quality in the Mediterranean region and proposed assessment methodology. $\begin{array}{lllll}\text { Agriculture, } \quad \text { Ecosystems } \quad \text { Environment, } & 88(2), & 137-146 .\end{array}$ http://dx.doi.org/10.1016/S0167-8809(01)00249-3 